\title{
Surveying shrimp aquaculture pond activity using multitemporal VHSR satellite images - case study from the Perancak estuary, Bali, Indonesia
}

\author{
Gusmawati Niken ${ }^{1,3 *}$, Soulard Benoit ${ }^{2}$, Selmaoui-Folcher Nazha ${ }^{1}$, Proisy Christophe ${ }^{4,5}$, \\ Mustafa Akhmad ${ }^{3}$, Le Gendre Romain ${ }^{2}$, Laugier Thierry ${ }^{2}$, Lemonnier Hugues ${ }^{2, *}$
}

${ }_{1}^{1}$ PPME, University of New Caledonia, BP R4, 98851 Nouméa, Cedex, New Caledonia

2 IFREMER LEAD-NC, BP 2059, 98846 Nouméa, Cedex, New Caledonia

${ }^{3}$ Agency of Research and Development for Marine and Fisheries, Ministry of Marine Affairs and Fisheries, Jakarta, Indonesia

${ }^{4}$ IRD/UMR AMAP, botAnique et bioinforMatique de l'Architecture des Plantes, TAA51/PS2, Boulevard de la Lironde, Montpellier, Cedex 5, France

${ }^{5}$ Laboratory of Geomatics and Applied Informatics (LIAG), French Institute of Pondicherry (IFP), UMIFRE 21 CNRS-MAEE/USR 3330, Pondicherry, India

* Corresponding author : Hugues Lemonnier, email address : hugues.lemonnier@ifremer.fr

niken.gusmawati@kkp.go.idm ; benoit.soulard@ifremer.fr ; nazha.selmaoui@univ-nc.nc ; christophe.proisy@ird.fr ; akhmadmustafa@yahoo.com ; romain.le.gendre@ifremer.fr ; thierry.laugier@ifremer.fr

\begin{abstract}
:
From the 1980's, Indonesian shrimp production has continuously increased through a large expansion of cultured areas and an intensification of the production. As consequences of diseases and environmental degradations linked to this development, there are currently 250,000 ha of abandoned ponds in Indonesia. To implement effective procedure to undertake appropriate aquaculture ecosystem assessment and monitoring, an integrated indicator based on four criteria using very high spatial optical satellite images, has been developed to discriminate active from abandoned ponds. These criteria were: presence of water, aerator, feeding bridge and vegetation. This indicator has then been applied to the Perancak estuary, a production area in decline, to highlight the abandonment dynamic between 2001 and 2015. Two risk factors that could contribute to explain dynamics of abandonment were identified: climate conditions and pond locations within the estuary, suggesting that a spatial approach should be integrated in planning processes to operationalize pond rehabilitation.
\end{abstract}




\section{Highlights}

- An integrated indicator was developed to survey shrimp ponds activity. This tool was developed using VHR satellite images. This indicator was tested to survey an aquaculture area in decline (2001-2015). Climate conditions explain the dynamics of pond abandonment. Findings indicate the need to consider spatial aspects to analyze the dynamic of pond abandonment.

Keywords : Aquaculture, Abandoned ponds, VHSR images Indicator, Supervised classification, Spatial and temporal survey 


\section{Introduction}

From 1980's, Indonesian shrimp production has continuously increased through a large conversion of mangrove areas as well as an intensification of production (Ilman et al., 2016). Total national shrimp production raised from $24,000 \mathrm{t}$ in 1980 to $585,000 \mathrm{t}$ in 2014 , representing an approximate increase rate of $65 \%$ year $^{-1}$ (FAO, 2016). Land use for brackish water tambak (pond) was estimated to 667,083 ha in 2014 (Ministry of Marine Affairs and Fisheries, 2015). At the same time, 613,194 farmers were working in shrimp industry, making shrimp the most important species in the fisheries sector with around a Free On Board value of 1706784.4 thousands USD (Ministry of Marine Affairs and Fisheries, 2015; Badan Pusat Statistik, 2016). Shrimp farming has become one of the primary sources of income for coastal communities. It supports rural economic development and contributes to national food security, employment and foreign exchange earnings. This sector has thus become strategic for economy of this country (Ministry of Marine Affairs and Fisheries, 2014).

Rapid growth in shrimp production, use of unsustainable production technologies and laxity in environmental regulation have generated negative ecological impacts on the environment as well as socio-economic issues on communities depending on coastal resources (Bhatta and Bhat, 1998). Impacts of shrimp farming include destruction of mangrove forests, salinization of coastal and agricultural lands, loss of genetic diversity in shrimp populations, conflicts over land rights and access to natural resources, and water pollution caused by discharge of pond waters (effluents) (Paez-Osuna, 2001). Effluents typically contain high concentrations of suspended particulate matter (mineral and organic), dissolved organic compounds, and nutrients (Briggs and Funge-Smith, 1994; Robertson and Phillips, 1995, Thomas et al., 2010). With emitted chemical and biological pollutants, which are redistributed among high-density farms through hydraulic vectors, problems of self-pollution and transmission of diseases were likely to occur in the ecosystem (Salama and Muray, 2011). Alteration of environmental 
suitability leads to stressful environmental conditions experienced by animals, which can increase disease incidence, and results in mass mortality and harvesting failure (Chanratchakool et al., 1995). Disease incidence that mostly hindered shrimp production in Indonesia was White Spot Disease (WSD). It was reported for the first time on Java island in 1994 and has become pandemic in Indonesia since then (Sunarto et al., 2004). As consequences of diseases and environmental degradations, there are currently 253,739 ha of abandoned shrimp ponds in Indonesia (37\% of the total surface of tambak) including 39,862 ha in Java (19\% of the total surface of tambak in this area), 100,461 ha (45\%) in Sumatra, 5,124 ha (3\%) in Sulawesi, 102,377 ha (33\%) in Kalimantan, and 5,965 ha (40\%) in Maluku, Lesser-Sunda (Ministry of Forestry, 2013), although an accurate estimation of the number of abandoned ponds is hard to obtain since land tenure records are often unreliable and out of date (Dahuri, 2012).

Indonesian government continues to encourage shrimp industry growth to ensure food security. For the Indonesian government, the target was to double shrimp production in the next decade from $0.3-0.4 \mathrm{t}$ to $0.6-1,0$ million tons by 2030 , quoting that there were $0.9-1.2$ million ha potential area for tambak development (Ministry of Marine Affairs and Fisheries, 2014, Ilman et al., 2016). To reach this goal, a strong development policy has been implemented by building farms in Sulawesi, Kalimantan and Papua, especially in mangrove areas. Rehabilitation of abandoned areas is the second implemented policy to reach this objective (Ilman et al., 2016). Three options are generally considered for pond restoration or rehabilitation (Bosire et al., 2008; Lewis III et al., 2003; Lewis III, 2005; Stevenson and Burdridge, 1997; Stevenson, 1997; Stevenson et al., 1999; Di Nitto et al., 2013): (1) rehabilitation of pond sites into sustainable shrimp production, (2) rehabilitation into alternative and sustainable rearing practices, and (3) restoration of environmental conditions within the pond and its surrounding area to rehabilitate the wetland ecosystem and its services 
(Duncan et al., 2016). However, rehabilitation of abandoned aquaculture area with the objective of maintaining an aquaculture activity was not considered at landscape or ecosystem scales, despite the fact that ponds are connected to each other and to open sea, and that rehabilitation of a pond should impact other ponds (Kausky et al., 2000; Salama and Murray, 2011; Tendencia et al., 2011a). In its code of conduct, FAO (1995) encouraged "to implement effective procedures to undertake appropriate environmental assessment and monitoring (...) and strategies and plans to ensure that aquaculture development is ecologically sustainable $(\ldots .) "$.

Within this framework, developing tools to assess shrimp pond status (ecological, sanitary, environmental pressure) and its resilience over time (historical or future) is pivotal to support decision makers in the elaboration of long-term planning of activity. Geographic information systems (GIS) and remote sensing tools using very high spatial resolution (VHSR) images have been already implemented for accurate mapping of aquaculture facilities (Dwivedi and Kandrika, 2005; Virdis 2014; Gusmawati et al., 2016) and for environmental surveys of aquaculture systems (e.g. Meaden and Aguilar-Manjarrez, 2013). This spatial data can include information on mangrove, shoreline, infrastructures, water, and soil condition. In the present work, we propose a methodology (Fig. 1) to develop an integrated indicator from GIS information and satellite images time series. This indicator should allow us to monitor changes in the activities of shrimp farms and should be able to discriminate active ponds from abandoned ponds. The indicator has been built from several combinations of criteria determined by cross-referencing field survey information and visually extracted information on satellite images at a given time period (2014-2015). A validation of this classification has been performed by applying a supervised classification method and an extractor of criteria association rules. Once the process is validated, we applied it to images from 2001 to 2015 to survey the dynamic of abandonment in a declining aquaculture area over this long period and 
to cross it with shrimp production and climate environment. Thus, we acknowledged the lesson learned from this site to steer all stakeholders towards a science-based approach to ensure long-term planning of activity and livelihood opportunities in an integrated coastal zone management (ICZM) framework.

\section{Materials and methods}

\subsection{Study site}

Perancak estuary system is located in the Jembrana Regency in southwestern Bali, Indonesia, near the city of Negara at $8^{\circ} 23^{\prime} 20^{\prime \prime S}$ and $114^{\circ} 37^{\prime} 20^{\prime \prime}$ E. Jembrana Regency is the second largest regency in Bali. The 2010 census noted rapidly growing urban population at approximately 273.3 thousand inhabitants. Perancak estuary covers approximately $7.5 \mathrm{~km}^{2}$ (Fig. 2). The main river is divided into four branches (Tukad Sowan, Tukad Daya Timur, Tukad Ijo Gading and Tukad Daya Barat) composing this estuarine system with the main orientation from North (mountainous area) to South (Indian Ocean). The central catchment region is mainly occupied by aquaculture ponds and mangrove-forested areas. This study site is particularly interesting due to the diversity of farming practices and the dynamics of mangrove (natural and anthropic settlements). It includes active shrimp ponds using semiintensive or intensive culture systems, abandoned shrimp ponds, fish ponds, polyculture ponds (algae/fish and shrimp), natural mangrove and mangrove plantations (Rahmania et al., 2015; Gusmawati et al., 2016). Furthermore, the study area is a typical example of land cover changes in coastal zones of Indonesia since the 80's. At that time, Perancak estuary was subject to aquaculture development and most of the mangrove forest was destroyed. Since the 90's, mangroves were reintroduced through plantations (Proisy et al. 2014, Proisy, this issue). Now, many shrimp ponds are abandoned but most of the pond dykes are kept operational by local government and owners. Perancak estuary thus experienced strong variability regarding 
land use and aquaculture effort. In order to support our comprehension of this aquaculture system in the Perancak area, shrimp production data within the Jembrana Regency over the 2000-2015 period was kindly provided by the Jembrana regency government. Brackishwater aquaculture production in Perancak estuary represents about $50 \%$ of the total production of Jembrana regency (Pemkab Jembrana, 2015).

\subsection{Data Collection}

\subsubsection{Time series of satellite images}

Fourteen VHSR images of Perancak estuary, acquired between 2001 and 2015, were purchased within the frame of the Indeso (Infrastructure Development of Space Oceanography) project. These optical images came from four different satellite sensors, namely IKONOS (images acquired on 12/10/01, 09/03/02, 21/02/03, and 27/06/03), Quickbird (22/09/07, 19/07/08, and 09/07/09), Worldview-2 (16/08/10, 15/04/11, 23/10/12, $10 / 12 / 13,26 / 03 / 14$, and 11/10/14) and Worldview-3 (16/04/15). Images covering the 20042006 period were not available. They were delivered in a GeoTIFF format. Pixel size varied from $50 \mathrm{~cm}$ to $1 \mathrm{~m}$ for panchromatic channel whereas the resolution of visible and infrared wavelengths ranged between 1.5 and $4 \mathrm{~m}$. Image analyses were based on multi-channel images composed of multi-spectral channels pan-sharpened to the spatial resolution of the panchromatic channel using $\operatorname{ArcGIS}^{\circledR}$ software. Those images were registered in UTM projection (WGS 84 datum, UTM zone 50s) using 40 ground control points (GCPs) that were collected in 2014 during a GPS survey (Garmin ${ }^{\circledR}$ GPSMAP 62SC). The co-registrations of all images were refined using the Worldview-3 image of 16 April 2015 as the reference image for superposition. The images used in this study were in sun-backward angular configurations to avoid amplification of sun backscattering and high brightness on water, which may mislead the identification of objects in the shrimp ponds. 


\subsubsection{Field surveys}

Field surveys were conducted in May 2014, November 2014 and June 2015. These surveys were dedicated to spatially reference aquaculture farming landscape: pond structures, aerators, bridges, status of ponds, mangrove extents, rivers, and human infrastructures. These three surveys permitted to explore the whole estuary area. It allowed us to locate abandoned and active ponds. Photographs and GPS positions were systematically recorded. Aims of the surveys were also to associate specific features that discriminate active from abandoned ponds. Moreover, this protocol was used to a posteriori validate the visual interpretation step (Fig. 1). Mangrove survey contributed to site analysis and knowledge (Rahmania et al., 2015; Proisy et al., 2014; Prosy, this issue). Twenty-three farmer were interviewed during field surveys in order to collect information about aquaculture practices. These interviews represented around half (176) of total ponds in activity (369). The questionnaire was developed in Bahasa Indonesia by The Research Institute of Coastal Aquaculture (RICA) and was administered by the main author with help from staff from RICA and local services (Institute for Marine Research and Observation). This staff was knowledgeable of farm operation and techniques used by farmers. The database contains technical information about farm locations, pond culture systems, sources of seed, water and feed management, disease outbreaks, harvests, pond infrastructures and sources of pollution.

\subsubsection{Climatic Environment}

Due to its geographical location, the hydro-climatic environment of Perancak estuary is strongly driven by the Asian-Australian monsoon system (As-syakur et al., 2013). Moreover, regional rainfall exhibits important inter-annual variability controlled mainly by the El NinoSouthern Oscillation (Vimont et al., 2010) and Indian Ocean Dipole (Saji and Yamagata, 
2003). Time series of monthly rainfall and temperature data over the 2001-2015 period, recorded at Negara weather station $\left(08^{\circ} 20^{\prime} 40^{\prime \prime} \mathrm{S}-114^{\circ} 36^{\prime} 98^{\prime \prime} \mathrm{E}\right)$, were provided by the Badan Meteorologi, Klimatologi dan Geofisika (BMKG). Based on this data, monthly anomalies were calculated for both atmospheric variables (Lozowski et al., 1989). Annual cumulated anomalies were then derived by summing monthly anomalies.

\subsection{Development of Indicators}

\subsubsection{Image Analysis}

Visual interpretation of image series was conducted to delineate various land cover types. The estuary zone which contains mangrove and shrimp farm was digitized. Since some images did not cover the entire estuary zone, the study area was restricted to the area covered by all images. The extent of the whole estuary was about $7.5 \mathrm{~km}^{2}$ and extent of the study area monitored through years was $7.1 \mathrm{~km}^{2}$. Main river, secondary and artificial channels were also delineated. They accounted for less than $1 \mathrm{~km}^{2}$ with slight variations between images due to newly constructed water channels or emergence of new mangrove islands. Combined use of very high spatial resolution (VHSR) and multispectral information (MI) allowed us to discriminate pond activities. Four main Boolean criteria were defined for this purpose based either or both features (VHSR or MI) of satellite images: 1) dry or full pond (MI), 2) presence of aerator(s) (MI), 3) presence of wooden feeding bridge(s) (VHSR), 4) presence of vegetation (VHSR $+\mathrm{MI})$. The presence of aerators and bridges appeared as discriminant criteria for active ponds, while presence of vegetation was considered as a significant criterion for abandoned ponds. Because ground truth was conducted between May 2014 and June 2015 , criteria validation was performed on data resulting from visual interpretation of three images acquired on 26/03/2014, 11/10/2014 and 16/04/2015, respectively. 


\subsubsection{Integrated Pond Activity Indicator}

An Integrated Pond Activity Indicator (IPAI) was developed, based on the four criteria described above. Sixteen possible combinations of criteria were used to define the activity status of ponds (Table 1). Ground truth allowed to establish simple empirical association rules to describe pond activity: if aerator and/or bridge are present in a pond then the pond is considered as active; if vegetation is observed then it is an inactive pond. Two associations over all possible combinations drew our attention. The first was case 9, i.e. absence of water, aerator, bridge and vegetation. Even though this case was defined later as an association rule that characterized inactive ponds (see section 2.5.), this rule could lead to misinterpretation as ponds could be active but in a dry period. The other one (case 12: presence of water but absence of aerator, bridge and vegetation) could also generate errors because corresponding ponds could hold extensive practice or could be abandoned but with presence of water due to tidal filling. In these two cases, pond status was determined based on other criteria. Indeed, soil color (when ponds were empty), water color (when ponds were filled), and presence or absence of dyke, were then used to help support knowledge-based visual interpretation of pond activity.

\subsubsection{Data Analysis}

A raw database was constructed by photo-interpretation. It consists of objects (ponds) described by criterion (absence or presence) defined above (aerator, water, bridge, etc.) and identified as active or non-active by ground truth. Ponds detected as active in the images of 2014 and 2015 thanks to the IPAI were compared to active ponds identified by ground truth. A supervised classification tool based on the decision tree method J48 (Quinlan, 1993) implemented in Weka software (Franck et al., 2016) was used (with 10 folds cross-validation) to evaluate the accuracy rate. This classification tool also provides a confusion matrix and a 
statistical kappa coefficient, which allowed for an accuracy assessment of the photointerpreted product. In addition, this tree decision method ranks criteria (here aerator, water, bridge, and vegetation) from strongest to weakest with respect to discrimination accuracy, by using information gain measure. Moreover, in order to refine pond activity characterization on a local scale, we applied a classification rule method (Agrawal and Srikant, 1994) implemented also in Weka on R software. This method returns sets of criteria values (here: presence, absence) that are associated with a class (here: active pond, inactive pond). In that context, an association rule is an expression of the form $\mathrm{Cr} 1, \mathrm{Cr} 2, \ldots, \mathrm{Crn} \rightarrow$ Class. Quality or power of an association rule can be measured. Two simple measures commonly used are frequency and confidence. In our case, frequency gives the number of ponds verifying the rule, and confidence quantifies the ratio between the number of ponds belonging to a class targeted by the rule and the number of ponds verifying criteria values $(\mathrm{Cr} 1, \mathrm{Cr} 2, \ldots, \mathrm{Crn})$.

\subsubsection{Application of the IPAI}

The IPAI developed in section 2.3.2 and validated in section 2.3.3 was applied on all VHSR images acquired between 2001 and 2015. The integrated pond activity maps were created on each date and arranged chronologically before proceeding to a temporal and spatial analysis of the aquaculture area.

\section{Results}

\subsection{Typology of farming systems in 2014-2015}

Land cover analysis in Perancak estuary brought out 1546 aquaculture ponds (Fig. 2). Among these ponds, 96 located in the northwest area were not visited during ground truth surveys. The area covered by aquaculture ponds was 360 ha ( $~ 53 \%$ of the region of interest - ROI) and abandoned ponds represented $70 \%$ of the total ponds. The number of active ponds was 369 . 
Pond locations were driven by the estuary shape.

Pond typology described below is predominantly based on agronomic criteria such as the type of production (fish, shrimp, etc.) and on production intensification factors (extensive to intensive inputs for feed and/or aeration) (Lazard et al., 2010). This typology is based on data and information collected during ground truth surveys.

Semi-intensive shrimp ponds represented $47 \%$ of total active ponds $(\mathrm{N}=172)$. For this type of production, facilities were earthen ponds of rectangular shape, with a surface ranging from 0.1 to 0.5 ha. Water depth varied between 0.6 and $1.2 \mathrm{~m}$. Stocking rate extended from 10 to 100 post-larvae per $\mathrm{m}^{2}$. Farmers used commercially formulated shrimp feeds in this system. One to three paddle wheel aerators were installed in ponds during the rearing period. Farmers used the same water gate for water exchange (inflow and outflow). Between culture periods, ponds were left dry for 1 to 10 weeks.

Intensive shrimp ponds accounted for $22 \%$ of total active ponds $(\mathrm{N}=83)$. Rearing facilities $(0.1-0.4 \mathrm{ha})$ were either earthen, liner or concrete ponds with a water depth of $1-1.5 \mathrm{~m}$. Distinct system features were a high stocking density $\left(100-160\right.$ post-larvae.m $\left.{ }^{-2}\right)$, a quite large number of aerators ( 4 per pond or more) and high feeding inputs. Water was pumped in the river and/or in groundwater. There were separate inlet and outlet gates and a drainage system in the central part of the pond.

Milkfish ponds were 89 , which amounted to $24 \%$ of total active ponds. These ponds were usually shallow (less than $1 \mathrm{~m}$ of water). In this type of system, one aerator per pond could be used. Feed was dispersed manually with or without feeding bridge. Some farms also used automatic feeders on dykes.

The last category consisted of two farms, thus representing approximately $4 \%(\mathrm{~N}=16)$ of total ponds in activity. These farms cultivated shrimp at high densities together with algae (Ulva spp.) in the same pond (Neori et al., 2004). Four paddle-wheel aerators and a bottom 
aerator were used by farmers to manage dissolved oxygen concentrations in ponds. Algae were cultured before shrimp stocking, in rows on pond surface as an algal mat. A first noticeable spatial feature derived from this 2014 analysis was, with few exceptions, that active ponds appeared to be mainly distributed in the upstream portion of Perancak estuary.

The intensive way of farming was predominately used near boundaries of this area, except for one small sector located near the main river fork. Regarding semi-intensive cultures, spatial patterns showed preferential positions in the western part of the whole area. Milkfish culture and polyculture did no display a clear spatial pattern although they were slightly more implanted in the central part.

\subsection{Criteria analysis}

In this section, we analyzed the distribution of criteria identified visually (section 2.3.1) on satellite images. Figure 3 shows maps representing the distribution of each criterion - water, aerator, feeding bridge and vegetation - at three dates (26/03/2014, 11/10/2014 and 16/04/2015). These maps allowed us to analyze how each criterion contributed to the characterization of pond activity as reported in ground truth. We performed the same analysis on a composite image of three dates for each criteria.

Water: ponds with the presence of water were mainly distributed in the aquaculture zone periphery (Fig. 3a). Among active ponds listed during ground truth campaigns, 34,7\% were filled with water on $26 / 03 / 2014,35.3 \%$ on $11 / 10 / 2014$, and $33,2 \%$ on $16 / 04 / 2015$.

Feeding bridge: ponds with the presence of feeding bridge were also scattered on Perancak estuary periphery (Fig. 3b). Among active ponds listed during ground truth campaigns, 51,5\% had a feeding bridge on $26 / 03 / 2014,51,5 \%$ on $11 / 10 / 2014$, and $55,3 \%$ on $16 / 04 / 2015$.

Aerator: All ponds with aerator(s) detected visually on superposed images were active ponds in ground truth data (Fig. 3c). One would think that aerator was a strong criterion of activity. 
However, there were many active ponds without aerators, as aerators were detected in $11,6 \%$ (26/03/2014), 10,8\% (11/10/2014) and 10,3\% (16/04/2015) of active ponds.

Vegetation: a strong colonization of ponds by mangrove was observed in Perancak estuary central zone (Fig. 3d). This colonization developed naturally and anthropically (Proisy et al., 2014; Rahmania et al., 2015). Moreover, active ponds without vegetation represented 97,7\%, $97,5 \%$ and $98,7 \%$ of active ponds reported in ground truth on the three dates, respectively.

Results related to each criterion showed that discrimination between active and inactive ponds required taking into account a combination of these criteria. Consequently, an integrated indicator was developed based on a supervised classification as well as the extraction of classification rules, as presented in the following section.

\subsection{Integrated Pond Activity Indicator}

Figure 4 shows the pond activity detected in the estuary in 2014 and 2015 using the IPAI. Active ponds were scattered at Perancak estuary periphery. Two evaluations were conducted to validate the IPAI. First, a decision tree classification method with 10 folds cross-validation was applied on this Boolean data. The decision tree revealed (Fig. 5) 87.8\% of correctly classified instances (ponds) with a kappa value of 0.66 . It provided a tree classification with a ranking of criteria, which showed that the feeding bridge criterion was the most discriminant (Fig. 5). Secondly, a classification rule method was performed to extract associations that concluded on pond activity status (for example: if aerator and bridge were present then pond was active). Table 2 presents the first twenty best rules extracted with higher frequency (> $70 \%$ ) and confidence (>90\%). Results validated that presence or absence of aerator, water, bridge, and vegetation could define pond activity status with a reliable degree of confidence. They also demonstrated that a combination of two or three criteria could be used to determine pond activity. For example, the absence of bridge and presence of vegetation characterized 
inactive ponds with a 0.99 degree of confidence. The best rule characterizing active ponds had a confidence of 0.84 . We also observed with both classification methods that presence or absence of aerator was not a discriminating criterion.

Similar analyses were conducted on each date separately (not shown). The combination of bridge and water criteria was enough to discriminate pond activity at the two 2014 dates. However, in 2015, vegetation criterion needed to be added to the combination bridge - water to discriminate pond activity status. Classification accuracies for the three dates were respectively $87 \%, 88 \%$ and $86 \%$.

We noticed that classes (active and inactive ponds) were unbalanced (with respect to the number of individuals). One issue related to supervised classification methods can be a bias towards majority classes (here inactive pond class). To overcome this problem, we balanced classes by removing ponds randomly from the majority class. Technically, this experiment was repeated several times. We obtained an average accuracy of $80 \%, 82.7 \%$ and $82.3 \%$ for each date respectively. So we obtained accuracy levels slightly lower than the ones reported above, but still fairly satisfactory.

In conclusion, feeding bridge (Fig. 5) appeared to be the most efficient criterion compared to aerator, water and vegetation, because it was firmly associated with activity in ground truth. It was also more likely to complement with other indicators such as vegetation and water to define active ponds. Aerators were not identified as a criterion by the classifier due to their absence in images, even though the presence of aerator could be discriminate criteria for activity indicator.

\subsection{Temporal and spatial analysis of pond activity}

The general trend exhibited a decrease in pond activity between 2001 and 2015 (Fig. 6a). However, results showed that the number of active ponds was quite similar between $12 / 10 / 01$ 
and 27/06/03 (period A) and between 22/09/2007 and 15/04/2011 (period C). A slight increase was even observed between 23/10/12 and 16/04/15 (period E). Consequently, the general trend could be explained by two drop periods. The first one was observed between mid-2003 and mid-2007 (period B) and the second between mid-2011 and mid-2012 period D).

Figure 6b displays the yearly cumulated climatic anomalies over the 2001-2015 period. It highlights three years presenting strong negative temperature anomalies reaching $-4^{\circ} \mathrm{C}$ in 2004 and approximately $-3^{\circ} \mathrm{C}$ in 2011 and 2012. These anomalies corresponded to the transition periods (B and D) when numbers of active ponds drastically dropped as shown in fig. 6a. Concerning annual rainfall anomalies, a positive anomaly (> $600 \mathrm{~mm}$ ) was detected in 2009 and in 2010.

Figure $6 c$ shows the variability of brackishwater production in Jembrana regency, as the production data associated with Perancak estuary was not available. A huge increase in shrimp Litopenaeus vannamei production was observed between 2002 and 2003 (from 250 to 2300 t). The production of Penaeus monodon ranged from 27 to $235 \mathrm{t}$ in 2005 and 2003 , respectively. This species was not reared anymore since 2006. Shrimp pond production decreased between 2004 and 2006, as well as between 2011 and 2012. Production data in fig. $6 \mathrm{c}$ tends to display similar period of changes as observed in figures $6 \mathrm{a}$ and $6 \mathrm{~b}$.

Figure 7 shows a map displaying the date when the last activity was detected in each pond. It reveals a gradient of abandonment from the center to the periphery of this agrosystem. The center zone became inactive earlier than the periphery and was in 2014 highly colonized by mangrove. Middle zone contained ponds that became inactive during $2004-2007$ period. Some of them were rehabilitated for polyculture and fish culture. Periphery zone comprised ponds which were still active between 2012 and 2015. 


\section{Discussion}

\subsection{Criteria detection by image analysis}

Visual image interpretation is the first approach in analysing satellite images that does not require a high expertise in the remote sensing field. This technique allowed us to easily identify various features and objects in Perancak estuary, such as mangrove trees, rivers, pond structures, aerators, feeding bridges and water in ponds; and around the estuary, such as urban settlements, agriculture (coconut plantations and rice fields) and rangeland. They were analyzed according to size, shape, pattern, tone, texture, shadow, position and spatial relationships as well as contrast and color saturation. To interpret images, object recognition, previous knowledge and experience rely on one another through an iterative process (Albertz, 2007). This task is nevertheless really time-consuming and can lead to errors because of human interpretations. Thus, next step in improving the present work will be to automate activity criteria detection, as already implemented for pond detection by image analysis (Gusmawati et al., 2016). Due to sub-metric image spatial resolutions, activity criteria, except "water" were detected in a quite confident manner. For aerators of about $2 \mathrm{~m}$ large, their true colors coupled with water splash due to blade rotation generate contrasting colors that make distinction possible. Feeding bridges of several meters long are also easily recognizable due to their rectangular shapes located above water. Discriminating vegetation has been widely studied (e.g. Lee and Yeh, 2009). A common method is the use of composite bands in a multispectral image that may contrast vegetation areas in abandoned ponds, such as the ratio of near-infrared band to red band. This ratio is known as the Ratio Vegetation Index (RVI). Another commonly used vegetation index is the Normalized Difference Vegetation Index (NDVI), which can also be utilized to automatically detect vegetation inside ponds. The most problematic criterion is clear water, because one could face cases where an active pond was not filled, or partially filled due to tidal oscillation, heavy rainfall on previous days before 
image acquisitions.

Identification cannot be conducted without VHSR images since medium and low spatial resolution images (> 4m) display fewer features and make difficult to differentiate between some earth and man-made materials (features) because of the mixed-pixel problem (Suwanprasit and Srichai, 2012). Studies were thus limited until the launch of new highresolution sensors, which occurred at the beginning of the 21 st century. In our study, Quickbird and Worldview-2 images made small object detection (e.g. feeding bridge) easier than IKONOS-2 images. Finer spatial resolution used in hyperspectral imagery or aerial photography is very promising since, for example, hyperspectral imagery can discriminate different wetland vegetation types (Ghioca-Robrecht et al. 2008). Nowadays, low-cost solutions to acquire VHSR images are emerging with the rapid development of Unmanned Aerial Vehicles which can be equipped with hyperspectral sensors.

As already stated in studies using satellite or aerial images, ground truth was crucial to ensure robustness of visual interpretation and associated conclusions (e.g. Meaden and AguilarManjarrez, 2013). In our study site, presence of mangrove trees inside ponds permitted to conclude to inactivity whereas in some aquaculture areas, mangrove is integrated into the farming system (Binh et al., 1997). For example in Gresik, East Java, traditional milkfish farmers keep mangrove growing inside ponds and on dykes (Schuster, 1952). The mangrove criterion should thus be considered as specific to some aquaculture areas. Feeding bridges, which here represented the most efficient criterion to build the IPAI used to detect activity in Perancak, wouldn't necessary be an appropriate criterion in traditional systems. However, aerators would probably be the most powerful criterion for assessment of activity in superintensive aquaculture areas. More generally, studies have shown that classification accuracy can be greatly improved by applying site-specific information, expert knowledge (empirical rules) and with addition of ancillary data to extract thematic features (e.g. vegetation groups, 
aerial photography, base region map, National Wetland Inventory maps) (Henderson et al., 1999; Gad and Kusky, 2006).

\subsection{Integrated Pond Activity Indicator}

We visually identified four factors (presence/absence of water, bridge, aerator and vegetation) as first criteria to detect pond activity. This integrated indicator was defined as a set of significant combinations of these four criteria, given in the form of decision rules either observed visually on images (Table 1) or extracted automatically based on ground truth (Table 2 and Fig. 5) using well-known supervised classification methods (decision tree and classification rules). Overall, obtained results confirmed, with a high statistical accuracy, the strength of the IPAI built automatically (Table 2). In addition, these decision rules should not only allow to determine pond activity status (active or inactive pond) but also to predict it on new images in order to monitor pond activity dynamics. This will allow avoiding systematic ground truth surveys, which are tedious and very expensive. Furthermore, visual interpretation by experts with sound experience is robust but still subjective. Indeed, in Table 1 , rules $\mathrm{N}^{\circ} 9$ and $\mathrm{N}^{\circ} 12$ corresponded to ponds for which expert could not visually identify the activity status on images, requiring additional information to make a decision (see section 2.4.3.). On the other hand, when rules were automatically extracted based on ground truth, $\mathrm{N}^{\circ} 9$ rule concluded on inactive ponds (Table 2) and $\mathrm{N}^{\circ} 12$ rule concluded on active ponds (Fig. 5). Even though presence/absence of water seems to dictate rule conclusions, some ponds could be in drying period or in discontinued production. Therefore, to differentiate these two situations more accurately, it is necessary to acquire more than two images a year. While field expertise remains essential to interpret and validate results, decision support with powerful, automatic and semi-automatic modeling tools can lessen subjectivity, reduce computation time and increases result accuracy. Furthermore, the approach used to build our 
IPAI is generic and can be reproduced while adding other criteria to reinforce and increase its robustness. In this study, we only considered four criteria that were simple to identify, but others such as image radiometric values or remote sensing indices (vegetation index, brightness index, etc.) could be involved in IPAI construction. For decades, spectral indices, such as vegetation and soil indices, have been used to predict, model and monitor different land change processes (Chen et al., 2012). Similarly, two and three-band indices have been utilized as water quality parameters in active aquaculture ponds (Abd-Elrahman et al., 2011). Ground truth revealed that pond abandonment for years might result in broken dykes, characteristic which might be used as a criterion to detect abandoned ponds. However, it could be only applied with the more recent images. State of disrepair of buildings such as warehouse, farmer hut, pumping station or central drainage system should also be additional characteristics to help to discriminate abandoned areas from active areas.

\subsection{Spatial and temporal changes in pond activity}

Temporal variation in pond activity in Perancak estuary followed a pattern similar to production variation for Jembrana region. This study suggested that two events were associated with farm abandonments, the first taking place between mid-2003 and mid-2007, and the second between mid-2011 and mid-2012. These abandonments were followed by a decrease in shrimp production. It is therefore worthwhile to look critically at how we can improve Indonesian (and elsewhere) shrimp farming by learning lessons from these observations.

The shrimp farm industries, based on the culture of $P$. monodon was devastated in Indonesia by white spot disease (WSD) from the mid-1980s continued to mid-2000s (Flegel, 2012). As reported by farmers, shrimp industry in Perancak estuary was also highly impacted by this disease, which was a major cause of farm abandonment. Production data from the Jembrana 
Regency showed that P. monodon culture was progressively abandoned from 2003 to 2006.

Litopenaeus vannamei was introduced as an alternative species, which was more resistant to WSD than P. monodon (Taukhid and Nur'aini, 2008). Because this species can be reared at very high density (> 100 shrimp. $\mathrm{m}^{-2}$ ), the production highly increased between 2002-2003 (Fig. 6c). As confirmed by farmers in the Perancak estuary, WSSD is still the most serious threat for all cultivated species of shrimp, including L. vannamei (Flegel, 2012).

Negative yearly temperature anomalies (low annual temperature comparatively to normal), recorded in 2004, 2011 and 2012 could be a significant factor of production drops. Use of cumulative variables in analysis of climate problems is not new. It derives from the idea that certain climate-driven quantities respond not only to "instantaneous" climate but to accumulated effects of climate variables over a period of time (Lozowski et al., 1989). Low atmospheric temperature, which affects water temperature, is reported as an important WSD risk factor (Tendencia et al., 2010a,b; 2011b). This anomaly could explain activity drops in Perancak estuary recorded between mid-2003 and mid-2007 and between mid-2011 and mid2012. Cases of high WSD prevalence in Ecuador in 1999 and Thailand in 2011 were induced by atmospheric temperature lower than normal (Rodríguez et al., 2003; Piamsomboon et al., 2016). Temperature is considered in the literature as a key factor to control WSD outbreaks. At low temperature $\left(26^{\circ} \mathrm{C}\right)$ comparatively to high temperature $\left(>30^{\circ} \mathrm{C}\right)$, viral replication increased and immune response decreased (Vidal et al., 2001; Reyes et al., 2007; Xue et al., 2015). WSD outbreaks could also be triggered by low salinity (Peinado-Guevara and LópezMeyer 2006). Van Thuong et al. (2016) indicate that during a drop in environmental salinity below 10, shrimp are at risk of white spot virus infection. Our study did not point out effects of rain anomalies, recorded in 2009 and 2010, on pond activity, thus suggesting that rain effects remained secondary compared to temperature in inducing mortality and pond abandonment, as already reported by Tendencia et al. (2010a). 
Other viral diseases have affected the production of L. vannamei in Indonesia (Taukhid and Nur'aini, 2008). A serious outbreak of Taura Syndrome Virus (TSV) occurred in early 2003 in northern East Java and has spread fast to other provinces since then. In 2006, high mortalities caused by the infectious myonecrosis virus (IMNV) were reported by Indonesian farmers on the island of Java (Senapin et al., 2007). By 2007, this disease had spread east to the neighboring island provinces of Bali and West Nusa Tenggara (Naim et al. 2014). Presence of these virus was recently confirmed in samples from Bali (Koesharyani et al., 2015). As reported for WSD, these virus remains serious threat for all cultivated species of shrimp and should be considered as additional factors weakening the shrimp production in the estuary.

Our results indicate the establishment of a gradient of abandonment from outskirt to center of the agrosystem over time. From 2000's, the cadastre showed a high density of ponds in activity. As a consequence, ponds were highly connected to each other. They could be considered as nodes in a connected network of water, wildlife, pathogenic agents and other processes such as nutrients exchanges (Amundrud et al., 2009, Frazer, 2009; Allen et al., 2016). In an epidemiological study, Tendencia et al. (2011a) showed that sharing of water source with other farms, use of the same receiving water source, and water change dependent on the tide, as in the Perancak estuary, increased the risk of disease development. We assumed that connectivity level within and among farms was critical in understanding the agrosystem regime shifts observed between 2000 and 2015. This network could be considered as a factor increasing eutrophication of the surrounding environment (too much effluent exported by farms in the same rivers), particularly in the center of the estuary. It could also increase the risk of pathogen spread (Mohan et al., 2008; Salama and Murray, 2011; Tendencia et al., 2011a). Moreover, eutrophication is known to promote pathogenic infection in aquatic species (Johnson et al., 2007). Our hypothesis is supported by data collected during 
the surveys of the present study, from farmer interviews, indicating that pond abandonments were mostly caused by low water quality and diseases. Water circulation in the estuary implied that some shrimp farms were more frequently exposed to suspended solids, organic compounds, nutrient matters and free-moving pathogenic agents in water than other farms (Wolanski, 2007). A high-resolution hydrodynamic model centered on Perancak estuary should be developed. Results from it could be used by farmers and stakeholders to limit disease-agent transmission by the river (Salama and Rabe, 2013). This tool will be useful for a better understanding of key factors triggering spatial distribution of pond activity.

\section{Conclusion and Perspectives}

An integrated indicator has been developed to survey shrimp ponds activity at a hydro - and agro - system scale. Using this tool, the aquaculture area history was described with a series of temporal satellite images. Until now, efforts to reduce the incidence of viral outbreaks has been mainly focused on zootechnical aspects at farm level (production of virus-free larvae; management practices such as soil removal and drying, liming and use of disinfectants; biosecurity measures; and water management (Corsin et al., 2001; 2005; Mohan et al., 2008). The present study confirms that a link exists between threat severity and climate conditions (Tendencia et al., 2011b), and highlights issues related to effects of climate on the development of disease in shrimp pond aquaculture (Harvell et al., 2002). However, our study also stresses the need to consider spatial aspects of risk linked to disease development. This risk could be lower in periphery than at the center of the estuary. Spatial resilience, also considered as spatial arrangement of, differences in, and interactions among internal and external elements of a system (Cumming, 2011), should be integrated in our future thinking to operationalize sustainable pond rehabilitation (Rist et al., 2014). 


\section{Acknowledgements}

This work was funded by the INDESO - CLS Project for Shrimp Farming Monitoring Application, which was led by Balitbang KP - Ministry of Marine Affairs and Fisheries, Indonesia. Within the framework of this project, the research has been carried out in agreement with all Indonesia laws and permits relative to research for foreigners and nationals. We gratefully acknowledge the referees' comments and suggestions. We would like to thanks our colleagues from the Institute for Marine Research and Observation, RICA (Research Institute for Coastal Aquaculture); the Local Service for Marine and Fisheries of Jembrana Regency (Bali); the Indonesian Agency for Meteorology, Climatology and Geophysics (BMKG); the Center of Research and Development for Marine and Coastal Resource (P3SDLP) for their help to collect data. We also thank Philippe Gaspar, Sophie Baudel, Rémi De Dianous, Nicolas Longepe, from "Collecte Localisation Satellites" (CLS) for the invitation to work on the Indeso Project.

\section{References}

Abd-Elrahman, A., Croxton, M., Pande-Chettri, R., Toor, G.S., Smith, S., Hill, J. 2011. In situ estimation of water quality parameters in freshwater aquaculture ponds using hyperspectral imaging system. ISPRS J. Photogram. 66(4), 463-472.

Agrawal, R., Srikant, R., 1994. Fast Algorithms for Mining Association Rules in Large Databases. In: 20th International Conference on Very Large Data Bases, 478-499.

Albertz, J. 2007. The Electromagnetic Spectrum and Atmospheric Transmittance. Einführung in die fernerkundung. Grundlagen der interpretation von luft- and satellitenbilder. Darmstadt. 254 pp.

Allen, C.R., Angeler, D.G., Cumming, G.S., Folke, C., Twidwell, D., Uden, D.R., 2016. Quantifying spatial resilience. J. Appl. Ecol. 53, 625-635.

Amundrud, T.L., Greathead, C., Gubbins, M.J., Davies, I.M., 2009. Nutrient release from coastal aquaculture: the importance of temporal aspects in species-specific production cycles. Aquac. Res. 40, 1563-1566.

As-syakur, A.R., Tanaka, T., Osawa, T., Mahendra, M.S., 2013. Indonesian rainfall variability observation using TRMM multi-satellite data. Int. J. Remo. Sens. 34(21), 7723-7738.

Badan Pusat Statistik, 2016. Ekspor Udang Menurut Negara Tujuan Utama, 2000 - 2014. http://bps.go.id/index.php/linkTabelStatis/1015.

Bhatta, R., Bhat, M., 2002. Impacts of aquaculture on the management of estuaries in India. Environ. Conserv., 25, 109-121.

Binh, C.T., Phillips, M.J., Demaine, H., 1997. Integrated shrimp-mangrove farming systems 
in the Mekong delta of Vietnam. Aquac. Res. 28, 599-610.

Bosire, J.O., Dahdouh-Guebas, F., Walton, M., Crona, B.I., Lewis III R.R., Field, C., Kairo, J.G., Koedam, N., 2008. Functionality of restored mangroves: A review. Aquat. Bot. 89, 251-259.

Briggs, M.R.P., Funge-Smith, S.J., 1994. A nutrient budget of some intensive marine shrimp pond in Thailand. Aquaculture and Fisheries Management 25, 789-811.

Chanratchakool, P., Pearson, M., Limsuwan, C., Roberts, R.J., 1995. Oxytetracycline sensitivity of Vibrio species isolated from diseased black tiger shrimp, Penaeus monodon, Fabricius. J. Fish. Dis. 18, 79-82.

Dwivedi, R.S., Kandrika, S., 2005. Delineation and monitoring of aquaculture areas using multi-temporal space-borne multispectral data. Curr Sci. India 89(8), 1414-1421.

Chen, X., Giri, C.P., Vogelmann, J.E., 2012. Land-Cover Change Detection. In: Remote Sensing of Land Use and Land Cover: Principles and Applications. Ed. Chandra P. Giri. CRC Press. Boca Raton. ISBN 9781420070743. 477p.

Corsin, F., Turnbull, J.F., Hao, N.V., Mohan, C.V., Phi, T.T., Phuoc, L.H., Tinh, N.N., Morgan, K.L., 2001. Risk factors associated with white spot syndrome virus infection in a Vietnamese ric-shrimp farming system. Dis. Aquat. Organ. 47, 1-12.

Corsin, F., J.F., Turnbull, C.V., Mohan, N.V., Hao, Morgan, K.L., 2005. Pond-level risk factors for White Spot disease outbreaks. In P. Walker, R. Lester and M.G. BondadReantaso (eds). Diseases in Asian Aquaculture V, pp. 75-92. Fish Health Section, Asian Fisheries Society, Manila.

Cumming, GS, 2011. Spatial resilience: integrating landscape ecology, resilience, and sustainability. Landscape Ecol. 26, 899-909.

Dahuri, R., 2012. Revitalisasi Tambak udang, Ciptakan pertumbuhan ekonomi berkelanjutan. Majalah Trobos. Edition June 2012. online version. (http://www.trobos.com/detailberita/2012/06/01/68/3419/prof-rokhmin-dahuri-revitalisasi-tambak-udang-ciptakanpertumbuhan-ekonomi-berkelanjutan) .

Di Nitto, D., Erftemeijer, P.L.A., van Beek, J.K.L., Dahdouh-Guebas, F., Higazi, L., Quisthoudt, K., Jayatissa, L.P., Koedam, N., 2013. Modelling drivers of mangrove propagule dispersal and restoration of abandoned shrimp farms. Biogeosciences 10, 50955113.

Duncan, C., Primavera, J.H., Pettorelli, N., Thompson, J.R., Loma, R.J.A., Koldewey, H.J. 2016. Rehabilitating mangrove ecosystem services: A case study on the relative benefits of abandoned pond reversion from Panay Island, Philippines. Mar. Pollut. Bull. 109, 772-782.

Dwivedi, R.S., Kandrika, S., 2005. Delineation and monitoring of aquaculture areas using multi-temporal space-borne multispectral data. Curr Sci. India 89, 1414-1421.

FAO, 1995. Implementation of the 1995 FAO Code of Conduct for Responsible Fisheries Web site. Code of Conduct for Responsible Fisheries. FI Institutional Websites. In: FAO Fisheries and Aquaculture Department [online]. Rome. Updated 16 February 2016. http://www.fao.org/fishery/code/en.

FAO, 2016. Fisheries and aquaculture software. FishStatJ - software for fishery statistical time series. In: FAO Fisheries and Aquaculture Department [online]. Rome. Updated 21 July 2016. http://www.fao.org/fishery/statistics/software/fishstatj/en.

Flegel, T.W., 2012. Historic emergence, impact and current status of shrimp pathogens in Asia. Journal of Invertebrate Pathology 110, 166-173.

Frank, E., Hall, M.A., Witten, I.H., 2016. The WEKA Workbench. Online Appendix for "Data Mining: Practical Machine Learning Tools and Techniques", Morgan Kaufmann, Fourth Edition, 2016.

Frazer, L.N., 2009. Sea-Cage Aquaculture, Sea Lice, and Declines of Wild Fish. Conservation Biology 23, 599-607. 
Gad, S,. Kusky, T., 2006. Lithological mapping in the Eastern Desert of Egypt, the Barramiya area, using Landsat thematic mapper (TM). J. Afr Earth Sci. 44, 196-202.

Ghioca-Robrecht, D.M., Johnston, C.A., Tulbure, M.G., 2008. Assessing the use of multiseason quickbird imagery for mapping invasive species in a lake Erie coastal marsh. Wetlands 28(4), 1028-1039.

Gusmawati, N., Zhi, C., Soulard, B., Lemonnier, H., Selmaoui-Folcher, N., 2016. Aquaculture ponds precise mapping in Perancak estuary, Bali, Indonesia. In: Proceedings of the 14th International Coastal Symposium Sydney, 6-11 March 2016. J. Coastal Res. SI75, 637-641. https://w3.ifremer.fr/archimer/doc/00347/45797/.

Harvell, C.D., Mitchell C.E., Ward, J.R., Altizer, S., Dobson, A.P., Ostfeld, R.S., Samuel, M.D., 2002. Climate Warming and Disease Risks for Terrestrial and Marine Biota. Science 296, 2158-2162.

Henderson, F.M., Hart, T.F.Jr., Henton, B.P., Portolese, J.E., 1999. Mapping Coastal Ecosystems Over A Steep Development Gradient using C-CAP Protocols. Int. J. Remote 58 Sens. 20(4),727-744.

Ilman, M., Dargusch, P., Dart, P., Onrizal, 2016. A historical analysis of the drivers of loss and degradation of Indonesia's mangroves. Land Use Policy 54, 448-459.

Johnson, P.T.J., Chase, J.M., Dosch, K.L., Hartson, R.B., Gross, J.A., Larson, D.J., Sutherland, D.R., Carpenter, S.R., 2007. Aquatic eutrophication promotes pathogenic infection in amphibians. PNAS 104, 15781-15786.

Kautsky, N., Rönnbäck, P., Tedengren, M., Troell., M., 2000. Ecosystem perspectives on management of disease in shrimp pond farming. Aquaculture 191, 145-161.

Koesharyani, I., Gardenia, L., and Mufidah, T. 2015. Distribution of infection taura syndrome, infectious myonecrosis and Penaeus vannamei nervous virus (TSV, IMNV, and PvNV) in Litopenaeus vannamei cultured in West Java, East Java, and Bali. Jurnal Riset Akuakultur 10(3), 415-422.

Lazard, J., Baruthio, A., Mathé, S., Rey-Valette, H., Chia, E., Clément, O., Aubin, J., Morissens, P., Mikolasek, O., Legendre, M., Levang, P., Blancheton, J-P., Rene, F., 2010. Aquaculture system diversity and sustainable development: fish farms and their representation. Aquat. Living Resour. 23, 187-198.

Lee, T-M., Yeh, H-C., 2009. Applying remote sensing techniques to monitor shifting wetland vegetation: A case study of Danshui River estuary mangrove communities, Taiwan. Ecol. Eng. 35, 487-496.

Lewis III, R.R., 2005. Ecological engineering for successful management and restoration of mangrove forests. Ecol. Eng. 24, 403-418.

Lewis, R.R. III, Phillips, M.J., Clough, B., Macintosh, D.J., 2003. Thematic Review on Coastal Wetland Habitats and Shrimp Aquaculture. Report prepared under the World Bank, NACA, WWF and FAO Consortium Program on Shrimp Farming and the Environment. Work in Progress for Public Discussion. Published by the Consortium. 81pp.

Lozowski, E.P., Charlton, R.B., Nguyen, C.D., Wilson, J.D., 1989. The Use of Cumulative Monthly Mean Temperature Anomalies in the Analysis of Local Interannual Climate Variability. J. Climate 2, 1059-1068.

Meaden, G.J., Aguilar-Manjarrez, J., eds. 2013. Advances in geographic information systems and remote sensing for fisheries and aquaculture. FAO Fisheries and Aquaculture Technical Paper No. 552. Rome, FAO. 425 p.

Ministry of Forestry, 2013. Rekalkulasi penutupan lahan Indonesia tahun 2012 (Land cover recalculation of Indonesia year 2012). Center for Forest Mappingand Inventory, Ministry of Forestry, Republic of Indonesia, Jakarta.

Ministry of Marine Affairs and Fisheries, 2014. Marine and Fisheries in Figures 2014. The Center for Data, Statistics and Information. Ministry of Marine Affaires and Fisheries of 
Indonesia. $340 \mathrm{pp}$.

Ministry of Marine Affairs and Fisheries, 2015. Marine and Fisheries in Figures 2015. The Center for Data, Statistics and Information. Ministry of Marine Affaires and Fisheries of Indonesia. $308 \mathrm{pp}$.

Mohan, C.V., Phillips, M.J., Bhat, B.V., Umesh, N.R., Padiyar, P.A., 2008. Farm-level plans and husbandry measures for aquatic animal disease emergencies. Rev. sci. tech. Int. Off. Epiz. 27, 161-173.

Naim, S., Brown, J.K., and Nibert, M.L. Genetic diversification of penaeid shrimp infectious myonecrosis virus between Indonesia and Brazil. Virus Research 189, 97-105.

Neori, A., Chopin, T., Troell, M., Buschmann, A.H., Kraemer, G.P., Halling, C., Shpigel, M.,Yarish, C., 2004 Integrated aquaculture: rationale, evolution and state of the art emphasizing seaweed biofiltration in modern mariculture. Aquaculture 231, 361-391.

Páez-osuna, F., 2001. The environmental impact of shrimp aquaculture: causes, effects, and mitigating alternatives. Env. manag. 28 131-140.

Peinado-Guevara, L.I., Lopez-Meyer, M., 2006. Detailed monitoring of white spot syndrome virus (WSSV) in shrimp commercial ponds in Sinaloa, Mexico by nested PCR. Aquaculture 251(1), 33-45

Pemkab Jembrana 2013. Profil Kabupaten Jembrana 2013. Bappeda dan Penanaman Modal Kabupaten Jembrana. 267 p.

Piamsomboon, P., Inchaisri, C., Wongtavatchai, J., 2016. Climate factors influence the occurrence of white spot disease in cultured penaeid shrimp in Chanthaburi province, Thailand. Aquacult. Environ. Interact. 8, 331-337.

Proisy, C., Rahmania, R., Viennois, G., Andayani, A., Baudel, S., Fahran, R., Gusmawati, N., Germain, O., Lemonnier, H., Mbay, N., Nugraha, B., Prosperi, J., Sidik, F., Subki, B., Suhardjonog, Widagti, N., Gaspar, P., 2014. Monitoring changes of mangroves coasts using high resolution satellite images. A case study in the Perancak estuary, Bali. $12^{\text {th }}$ Biennial conference of Pan Ocean Remote Sensing, Conference (PORSEC-2014) 04-07 November 2014, Bali-Indonesia.

Quinlan, R., 1993. C4.5: Programs for Machine Learning. Morgan Kaufmann Publishers, San Mateo, CA.

Reyes, A., Salazar, M., Granja, C., 2007. Temperature modifies gene expression in subcuticular epithelial cells of white spot syndrome virus- infected Litopenaeus vannamei. Dev. Comp. Immunol. 31, 23-29.

Rahmania, R., Proisy, C., Viennois, G., Andayani, A., Subki, B., Farhan, A.R., Gusmawati, N.F., Lemonnier, H., Germain, O., Gaspar, P., Prosperi, J., Sidik, F., Widagti, N., Suhardjono, 2015. 13 Years of changes in the extent and physiognomy of mangroves after shrimp farming abandonment, Bali. 8th International Workshop on the Analysis of Multitemporal Remote Sensing Images (Multi-Temp), Annecy, France, pp. 1-4). http://dx.doi.org/10.1109/Multi-Temp.2015.7245801

Rist, L., Felton, A., Nyström, M., Troell, M., Sponseller, R.A., Bengtsson, J., Österblom, H., Lindborg, R., Tidåker, P., Angeler, D.G., Milestad, R., Moen, J., 2014 Applying resilience thinking to production ecosystems. Ecosphere 5, 1-11.

Robertson, A.I., Phillips, M.J., 1995. Mangroves as filters of shrimp pond effluent: predictions and biogeochemical research needs. Hydrobiologia 295, 311-321.

Rodríguez J, Bayot B, Amano Y, Panchana F, De Blas I, Alday V, Calderón J (2003) White spot syndrome virus infection in cultured Penaeus vannamei (Boone) in Ecuador with emphasis on histopathology and ultrastructure. J Fish Dis 26, 439-450.

Saji, N.H., Yamagata, T., 2003. Possible impacts of Indian Ocean dipole mode events on global climate. Clim. Res. 25(2), 151-169.

Salama, N.K.G., Murray, A.G., 2011. Farm size as a factor in hydrodynamic transmission of 
pathogens in aquaculture fish production. Aquacult. Environ. Interact. 2, 61-74.

Salama, N.K.G., Rabe, B., 2013. Developing models for investigating the environmental transmission of disease-causing agents within open-cage salmon aquaculture. Aquacult. Environ. Interact. 4, 91-115.

Schuster, W.H., 1952. Fish culture in Brachish-water ponds of Java. ed. G.L. Kesteren, D.Sc.. Indo-Pacific Fisheries Council, special publication $\mathrm{n}^{\circ} 1,148 \mathrm{pp}$.

Senapin, S., Phewsaiya, K., Briggs, M., Flegel, T.W., 2007. Outbreaks of infectious myonecrosis virus (IMNV) in Indonesia confirmed by genome sequencing and use of an alternative RT-PCR detection method. Aquaculture, 266, 32-38.

Stevenson, N.J., 1997. Disused Shrimp Ponds: Options for Redevelopment of Mangrove. Coast. Manag. 25, 423-425.

Stevenson, N.J., Lewis, R.R., Burbridge, P.R., 1999. Disused shrimp ponds and mangrove rehabilitation. In: In: Streever WJ (ed). An International perspective on wetland rehabilitation. Kluwer, Netherlands, pp. 227-297.

Sunarto, A., Widodo, Taukhid, Koesharyani, I., Supriyadi, H., Gardenia, L., and Sugianti, B. 2004. Current status of transboundary fish diseases in Indonesia: Occurrence, surveillance, research and training: Country report. In Lavilla- Pitogo, C.R., Nagasawa, K.. Proceeding of The meeting on Transboundary Fish Diseases in South East Asia: Occurrence, Surveillance, Research and Training. Manila, The Philipines 23-24 June 2004. Aquaculture Department Southeast Asian Fisheries Development Center Iloilo, Philippines.

Suwanprasit, C., Srichai, N., 2012. Impacts of spatial resolution on land cover classification. Proceedings of the Asia-Pacific Advanced Network 33, 39-47.

Taukhid and Nur'aini, Y.L. 2008. Infectious Myonecrosis Virus (IMNV) in Pacific White Shrimp, Litopennaeus vannamei in Indonesia. Indonesian Aquaculture Journal 3(2), 139146.

Tendencia, E.A., Bosma, R.H., Usero, R.C., Verreth, J.A.J., 2010a. Effect of rainfall and atmospheric temperature on the prevalence of white spot syndrome virus (WSSV) in pond cultured Penaeus monodon. Aquac. Res. 41, 594-597.

Tendencia, E.A., Bosma, R.H., Verreth, J.A.J., 2010b. WSSV risk factors related to water physico-chemical properties and microflora in semi-intensive Penaeus monodon culture ponds in the Philippines. Aquaculture 302, 164-168.

Tendencia, E.A., Bosma, R.H., Verreth, J.A.J., 2011a. White spot syndrome virus (WSSV) risk factors associated with shrimp farming practices in polyculture and monoculture farms in the Philippines. Aquaculture 311, 87-93.

Tendencia EA, Verreth JAJ. 2011b. Temperature fluctuation, low salinity, water microflora: risk factors for WSSV outbreaks in Penaeus monodon. Isr J Aquacult-Bamid 63: 1-7

Thomas, Y., Courties, C., El Helwe, Y., Herbland, A., Lemonnier, H., 2010. Spatial and temporal extension of eutrophication associated with shrimp farm wastewater discharges in the New Caledonian Lagoon. Mar. Pollut. Bull. 61, 387-398.

Van Thuong, K., Van Tuan, V., Li, W., Sorgeloos, P., Bossier, P., Nauwynck, H., 2016. Effects of acute change in salinity and moulting on the infection of white leg shrimp (Penaeus vannamei) with white spot syndrome virus upon immersion challenge. J. Fish Dis. 39, 1403-1412.

Vidal, O.M., Granja, C.B., Aranguren, F., Brock, J.A., Salazar, M., 2001. A profound effect of hyperthermia on survival of Litopenaeus vannamei juveniles infected with white spot syndrome virus. J. World Aquacult. Soc. 32, 364-372.

Vimont, D.J., Battisti, D.S., Naylor, R.L., 2010. Downscaling Indonesian precipitation using large-scale meteorological fields. Int. J. Climatol. 30(11), 1706-1722.

Virdis, S.G.P., 2014. An object-based image analysis approach for aquaculture ponds precise mapping and monitoring: a case study of Tam Giang-Cau Hai Lagoon, Vietnam. Environ. 
Monit. Assess. 186, 117-133.

Wolanski, E., 2007. Chapter 2 - Estuarine water circulation. In: Estuarine Ecohydrology. Elsevier, Amsterdam, pp. 17-39.

Xue, S., Wei, J., Li, J., Geng, X., Sun, J., 2015. Effects of total ammonia, temperature and salinity on the mortality and viral replication of WSSV-infected Chinese shrimp (Fenneropenaeus chinensis). Aquac Res DOI:10.111/are. 12877 
Table 1. Combination of activity indicators (+ : presence; - : absence) to develop an integrated activity indicator using visual interpretation. A pond with aerator or with bridge is necessarily considered as active (cells in light grey) and a pond with vegetation is necessarily considered as inactive (cells in dark grey).

\begin{tabular}{cccccc}
\hline No & Aerator & Water & Bridge & Vegetation & Activity \\
\hline 1 & + & + & + & - & \\
2 & + & + & - & - & \\
3 & + & - & + & - & \\
4 & - & + & + & - & \\
5 & + & - & - & - & \\
6 & - & - & + & - & \\
7 & + & + & - & + & \\
8 & + & - & + & + & \\
9 & - & - & - & - & determined by appraisal \\
10 & - & + & + & + & \\
11 & - & - & + & + & \\
12 & - & + & - & - & determined by appraisal \\
13 & + & + & + & + & \\
14 & + & - & - & + & + \\
15 & - & + & - & + & + \\
16 & - & - & - & & + \\
\hline
\end{tabular}


Table 2. Best rules to identify pond activity using four activity indicators (Water, Aerator, Bridge, and Vegetation) extracted by classification rule method; presence: +; absence: -

\begin{tabular}{|c|c|c|c|c|c|c|}
\hline No & Aerator & Water & Bridge & Vegetation & $\begin{array}{c}\text { Activity } \\
\text { Survey }\end{array}$ & $\begin{array}{c}\text { Degree of } \\
\text { confidence }\end{array}$ \\
\hline 1 & & & - & + & - & 0.99 \\
\hline 2 & - & & - & + & - & 0.99 \\
\hline 3 & & - & - & + & - & 0.99 \\
\hline 4 & - & - & - & + & - & 0.99 \\
\hline 5 & & & & + & - & 0.99 \\
\hline 6 & - & & & + & - & 0.99 \\
\hline 7 & & - & & + & - & 0.99 \\
\hline 8 & - & - & & + & - & 0.99 \\
\hline 9 & & - & - & & - & 0.9 \\
\hline 10 & - & - & - & & - & 0.9 \\
\hline 11 & - & & - & & - & 0.88 \\
\hline 12 & & & - & & - & 0.88 \\
\hline 13 & & & + & - & + & 0.84 \\
\hline 14 & & & + & & + & 0.83 \\
\hline 15 & - & - & & & - & 0.83 \\
\hline 16 & & - & & & - & 0.82 \\
\hline 17 & & - & - & - & - & 0.81 \\
\hline 18 & - & - & - & - & - & 0.81 \\
\hline 19 & - & & + & - & + & 0.81 \\
\hline 20 & - & & + & & + & 0.80 \\
\hline
\end{tabular}




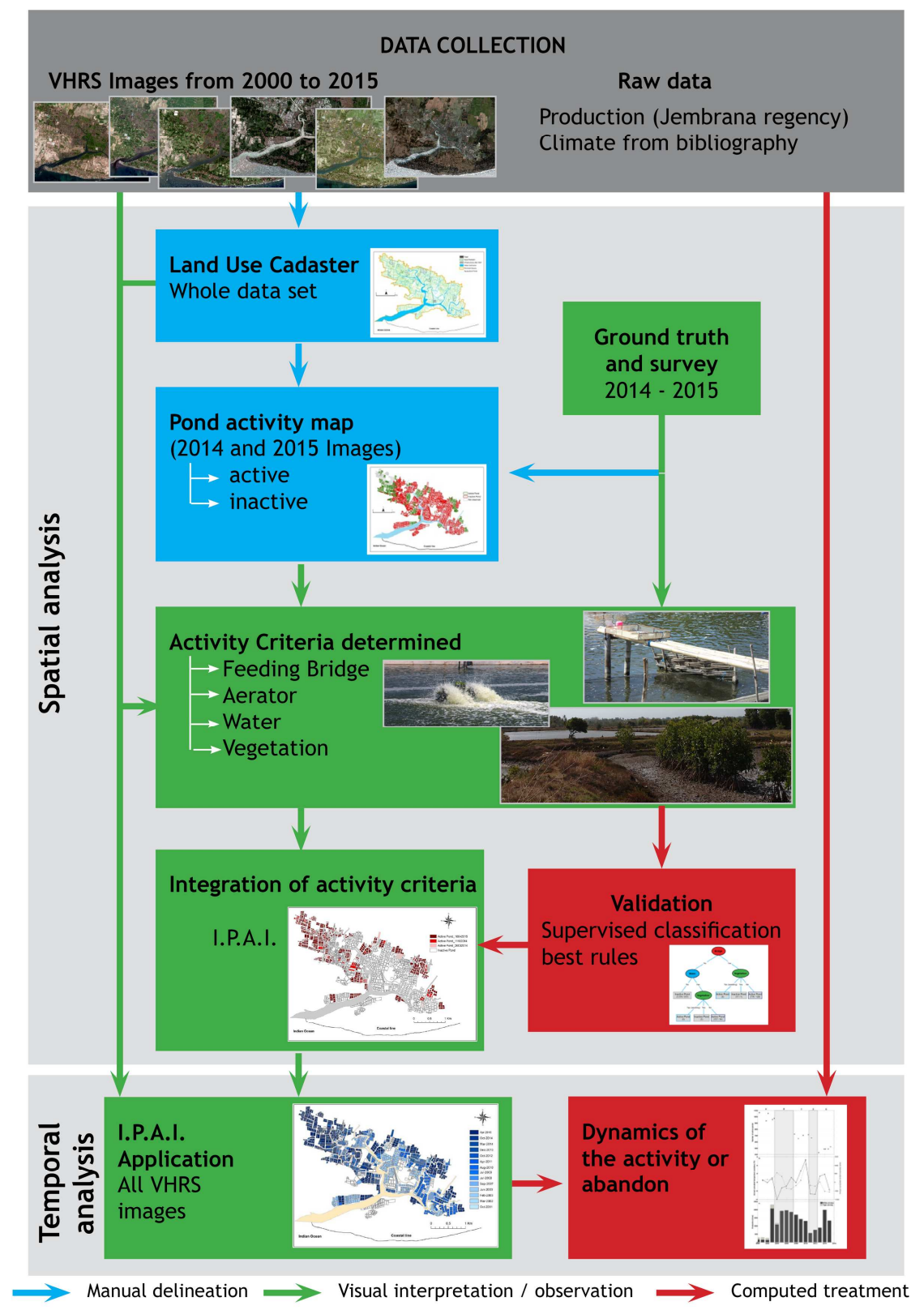

Fig. 1: Flowchart of combined ground and VHSR satellite image processing and analysis for monitoring aquaculture pond activity. 


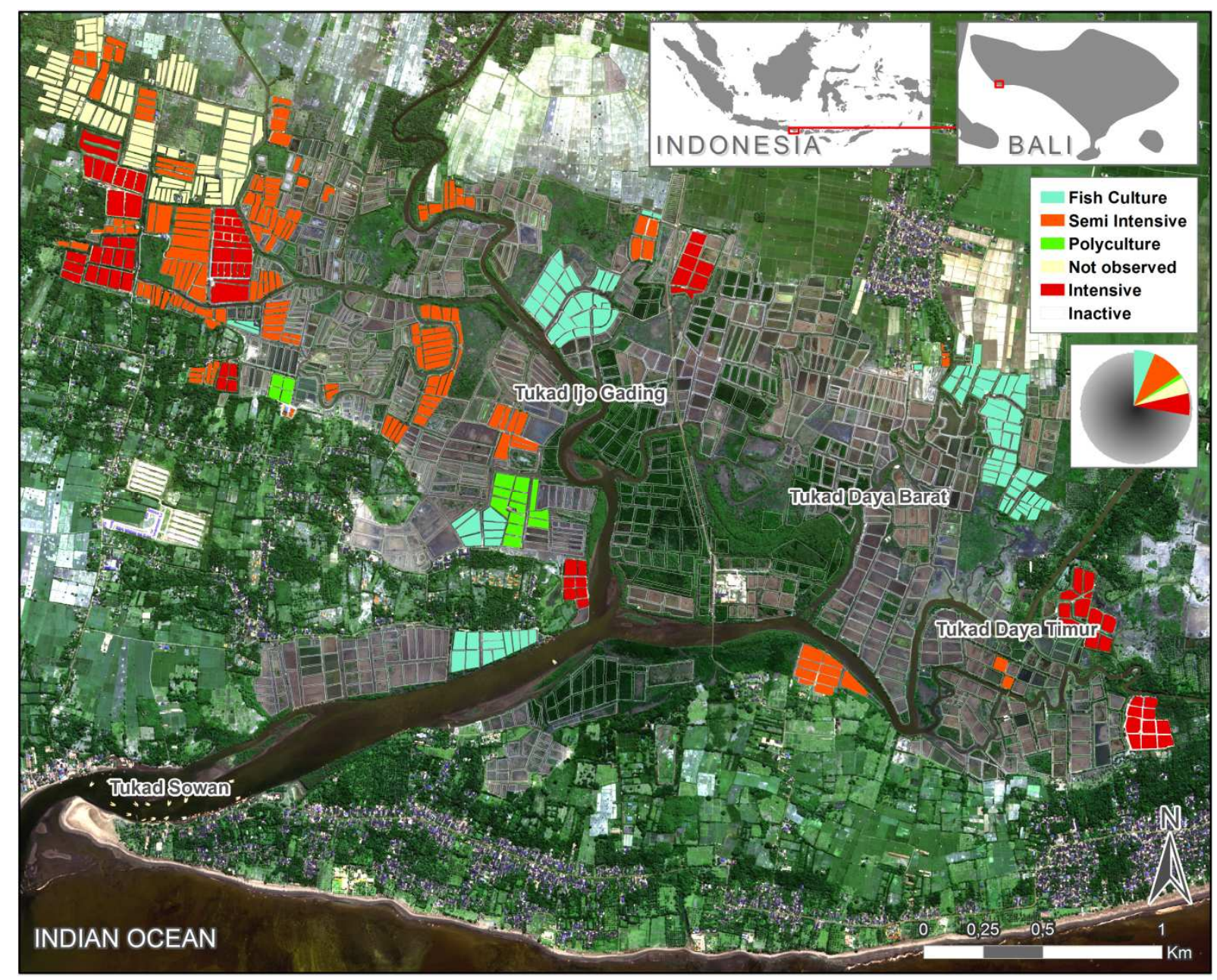

Fig. 2. Aquaculture production systems in Perancak estuary in 2014 established using data collected during field surveys. The pie chart represents the proportions of fish culture, polyculture, semi-intensive, intensive, not observed and inactive ponds to total number of ponds $(\mathrm{N}=1546)$. 


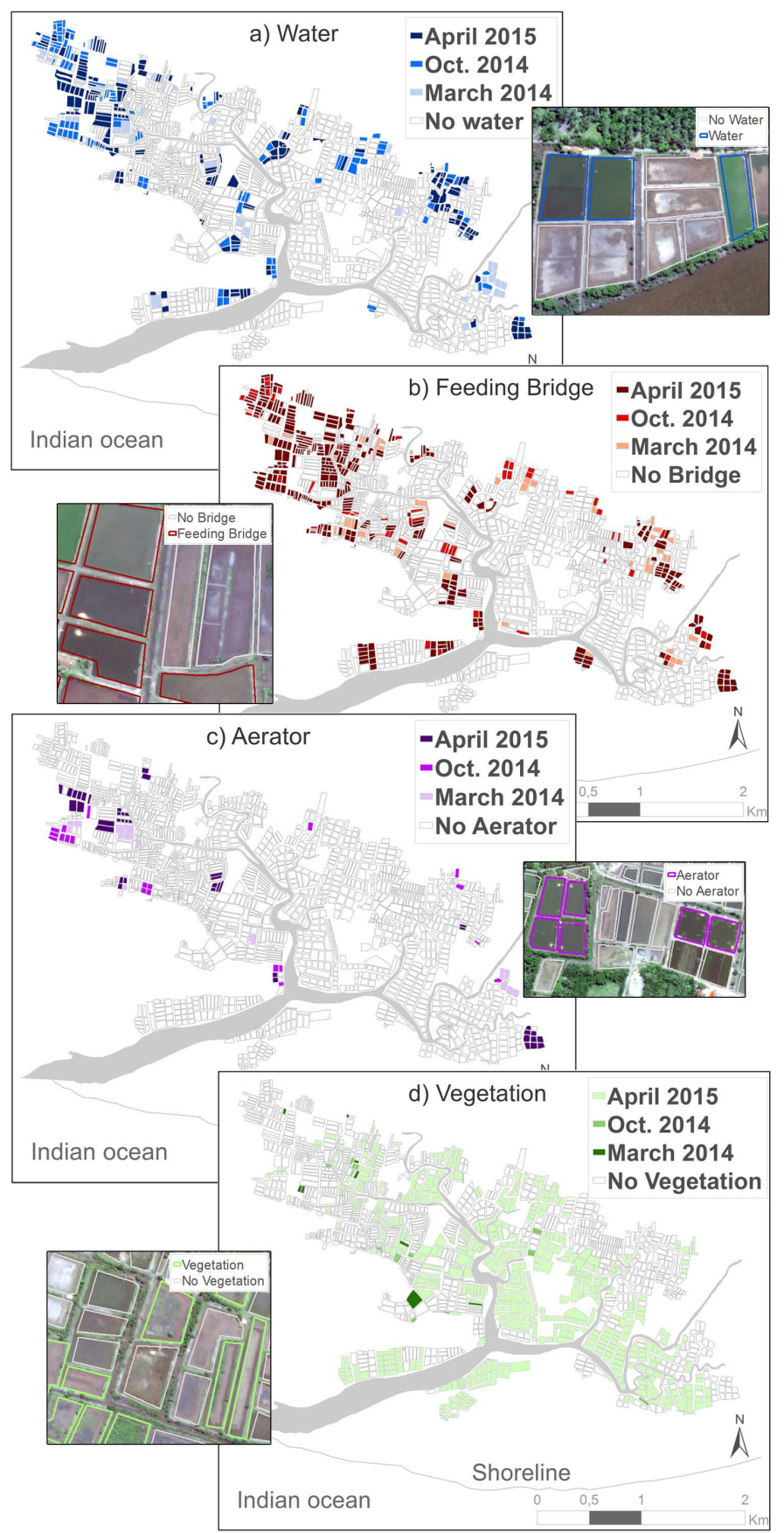

Fig. 3. Criteria detected by visual interpretation in Perancak estuary in 2014 and 2015. (a)

Water; (b) Feeding Bridge; (c) Aerator; and (d) Vegetation 


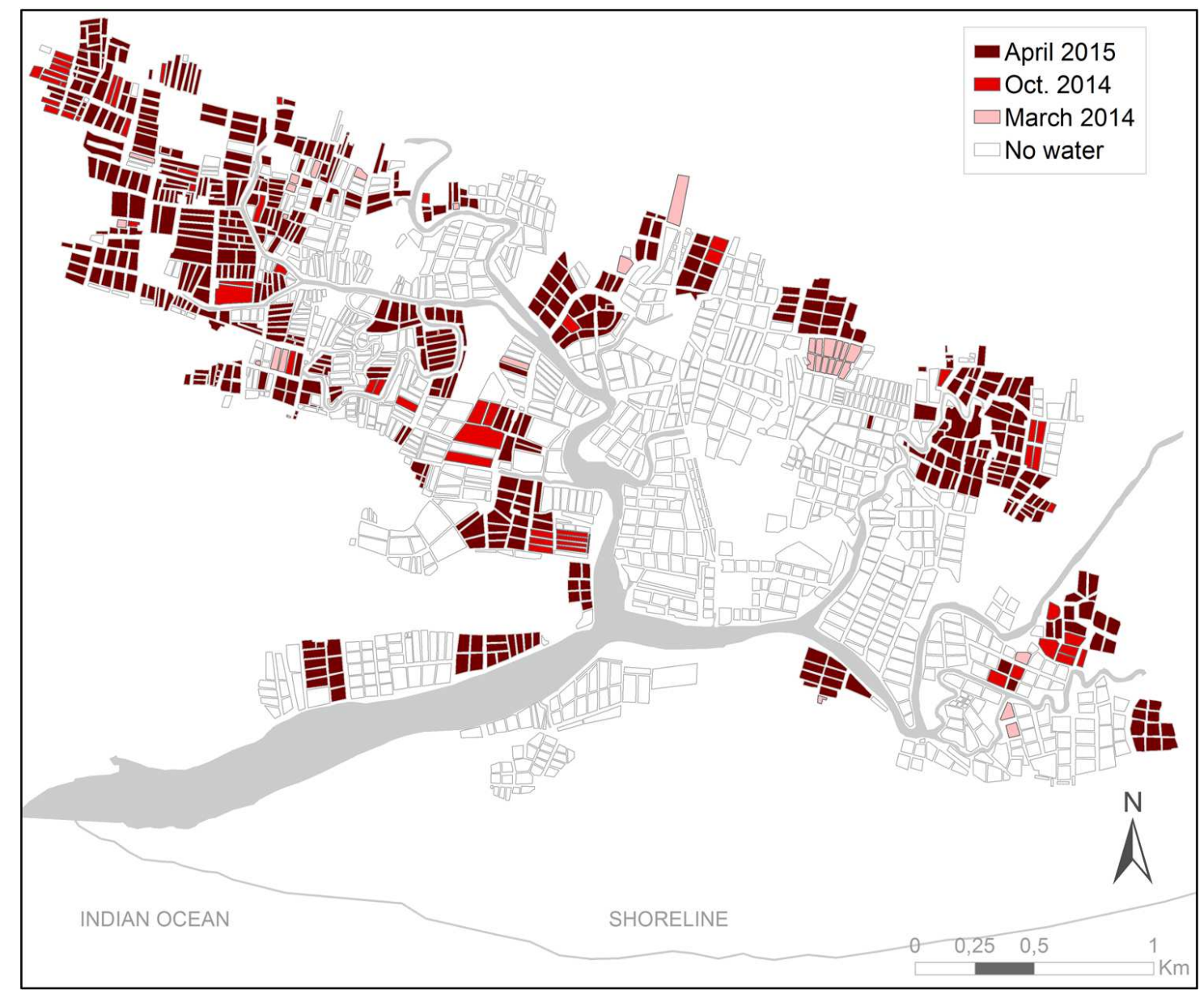

Fig. 4. Pond activity detected in Perancak estuary in 2014 and 2015, based on integrated pond activity indicator (IPAI). 


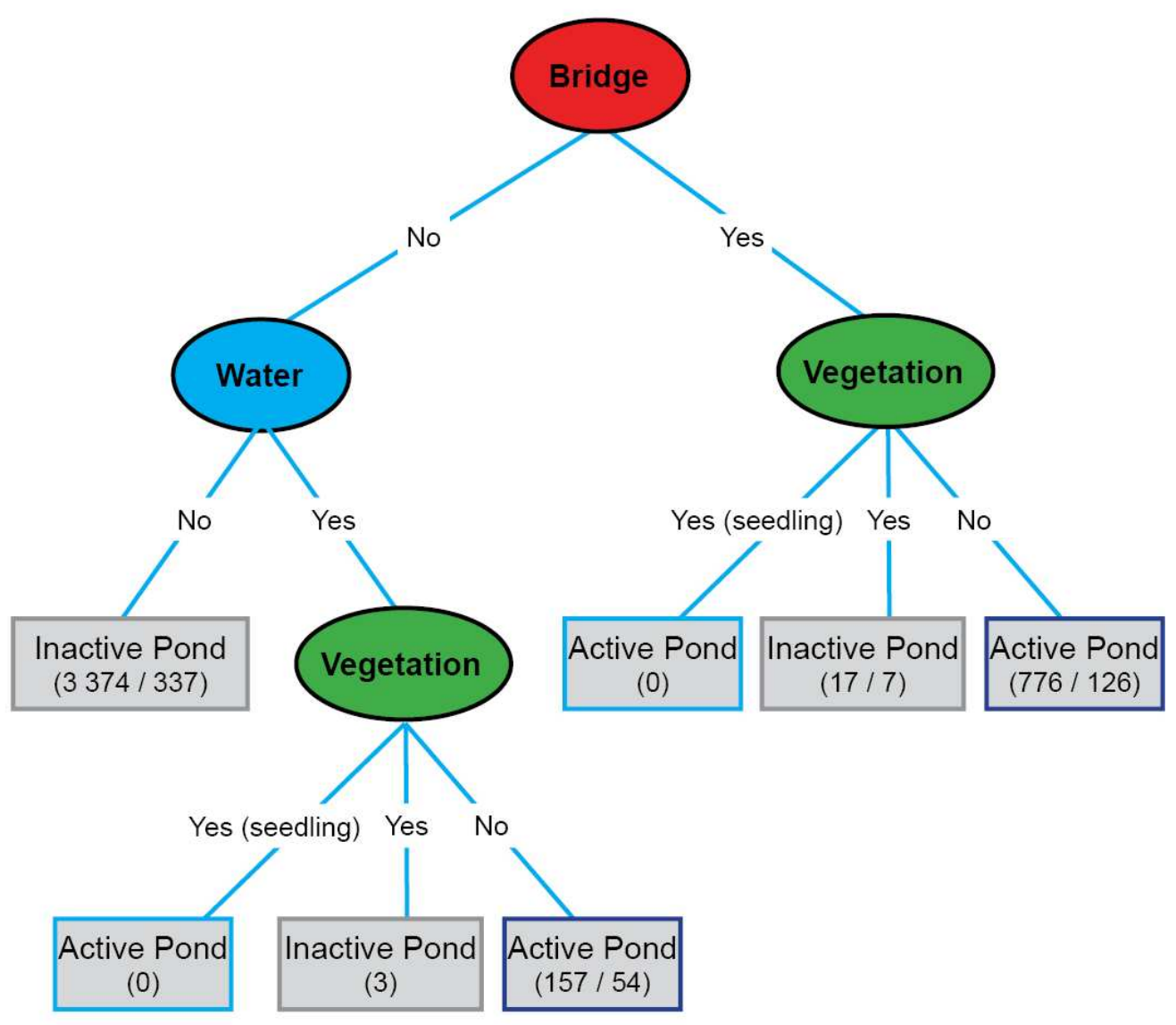

Fig. 5. Classification of activity indicators using decision tree method. Bridge was the strongest indicator. (Bridge as root; Water and Vegetation as Internal Nodes; Active and Inactive Pond as leaf nodes). The first number represents the total number of instances reaching the leaf. The second number accounts for the number of those instances that are misclassified. 


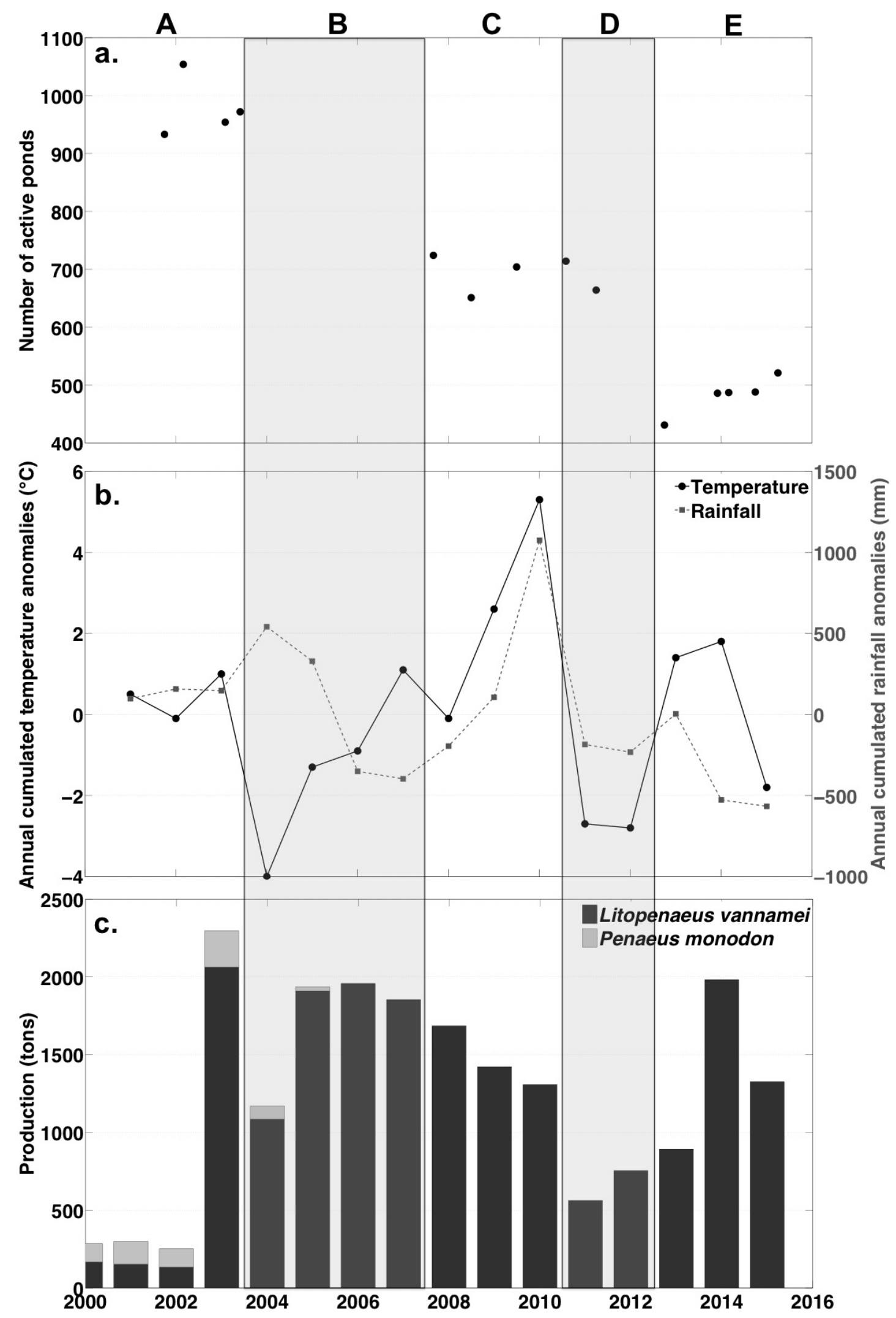

Fig. 6. Temporal analysis of activity in Perancak estuary (2000 - 2015). (a) Number of active ponds based on integrated activity indicator; (b) Annual cumulated temperature and rainfall anomalies; (c) Brackishwater aquaculture production in Perancak estuary. It represents about 50\% of the total production of Jembrana regency. Capital letters show the different periods identified between 2000 and 2015 


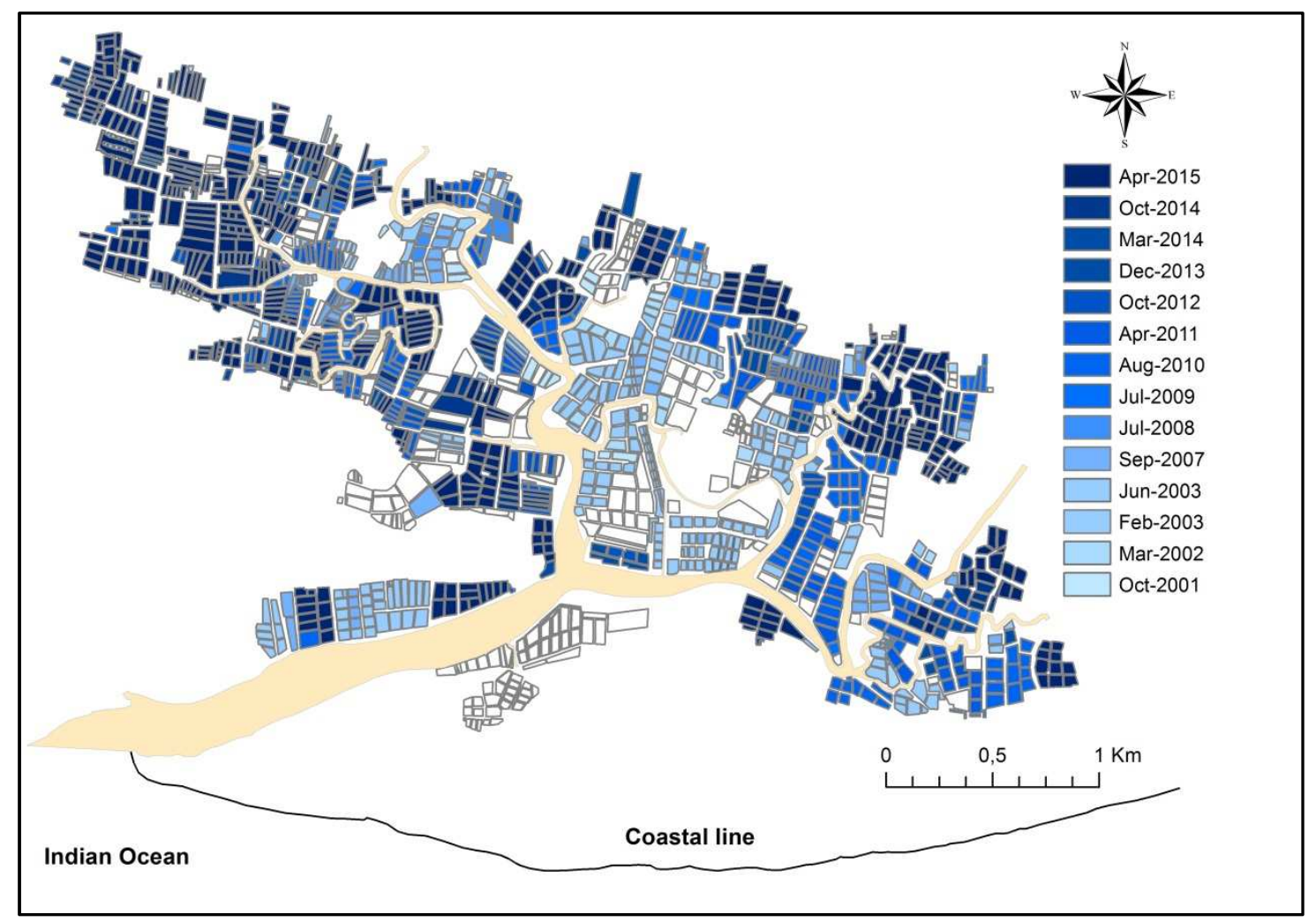

Fig. 7: Cadastre of the last activity detected in ponds between 2001 and 2015 in Perancak estuary, based on integrated pond activity indicator (IPAI). 